\title{
Dao, Harmony and Personhood: Towards a Confucian Ethics of Technology
}

\author{
Pak-Hang Wong
}

Received: 20 January 2011 /Accepted: 28 March 2011 /Published online: 9 April 2011

C The Author(s) 2011. This article is published with open access at Springerlink.com

\begin{abstract}
A closer look at the theories and questions in philosophy of technology and ethics of technology shows the absence and marginality of non-Western philosophical traditions in the discussions. Although, increasingly, some philosophers have sought to introduce non-Western philosophical traditions into the debates, there are few systematic attempts to construct and articulate general accounts of ethics and technology based on other philosophical traditions. This situation is understandable, for the questions of modern sciences and technologies appear to be originated from the West; at the same time, the situation is undesirable. The overall aim of this paper, therefore, is to introduce an alternative account of ethics of technology based on the Confucian tradition. In doing so, it is hoped that the current paper can initiate a relatively uncharted field in philosophy of technology and ethics of technology.
\end{abstract}

Keywords Chinese philosophy · Confucian ethics · Virtue ethics · Role-based ethics · Social role $\cdot$ Ethics of technology $\cdot$ Amelioration

\section{Introduction}

Recent proliferation of handbooks, companions, and encyclopaedia entries on philosophy of technology and ethics of technology has, by and large, indicated and confirmed their status in mainstream philosophy. ${ }^{1}$ If one takes a closer look at the theories and questions discussed in those venues, however, it is difficult not to recognise the absence and marginality of non-Western philosophical traditions. Although, increasingly, some philosophers, notably those who are interested in inter-/cross-cultural issues and those who are in the field of bioethics and

\footnotetext{
${ }^{1}$ See, e.g. Meijers (2009), Olsen et al. (2009a, 2009b), Franssen et al. (2010).

P.-H. Wong $(\bowtie)$

Department of Philosophy, Faculty of Behavioral Sciences, University of Twente, Postbox 217, 7500

AE Enschede, The Netherlands

e-mail: p.h.wong@utwente.nl

URL: http://www.wongpakhang.com
} 
environmental philosophy, have sought to introduce non-Western philosophical traditions into the debates, there are few systematic attempts to construct and articulate general accounts of ethics and technology based on other philosophical traditions. ${ }^{2}$ This situation is understandable, for the questions of modern sciences and technologies appear to originate from the West; at the same time, the situation as such is undesirable. As Kupperman (2010a) has pointed out, the lone focus on Western philosophical traditions has an inevitable narrowing effect. The overall aim of this paper, therefore, is to introduce an alternative account of ethics and technology based on the Confucian tradition. In doing so, it is hoped that the current paper can initiate a relatively uncharted field in philosophy of technology and ethics of technology.

Immediately, there are two major challenges for this task. First, the Confucian tradition covers an enormous field of study including its metaphysics, epistemology, and ethics, which is impractical, if not impossible, to include in the current paper. Second, there are numerous, conflicting interpretations of Confucianism from its early history to the present. Hence, it is perhaps more appropriate to speak of many Confucianisms than the Confucian tradition. To answer the first challenge, I will restrict the current discussion only to those notions that are most relevant for an account of ethics and technology in a Confucian perspective, i.e. Dao, harmony $\mathrm{He}$, and personhood. To answer the second challenge, I shall elaborate a least controversial interpretation of Confucianism by identifying the basics that are shared or, at least, can be shared, by various interpretations. ${ }^{3}$

\section{Dao: The Foundation of Confucianism}

The term 'Dao' is often linked to Daoism, i.e. a major rival to Confucianism, but, as a matter of fact, it is one of the most important notions in Chinese

\footnotetext{
${ }^{2}$ For examples in intercultural information ethics (also known as 'global information ethics'), see, e.g. Ess (2006, 2007a, b, 2008, 2009), Ess and Hongladarom (2007), Ess and Thorseth (2010), Capurro (2008, 2010); in bioethics, see Fan (1999), and in environmental ethics, see Lai (2003). The aforementioned studies are all useful attempts to introduce Chinese philosophical traditions into the debates related to philosophy of technology and ethics of technology. However, none of them have provided a general account of ethics of technology from a Chinese philosophical perspective. Similarly, Bockover (2003) has analysed the impact of Internet on Confucian values, but her account is primarily negative and does not offer a positive account of Confucian ethics for internet. The most comprehensive attempt to formulate a Confucian ethics of technology can be found in Wang (2002), but the current paper differs from hers in that it aims at constructing and articulating a Confucian ethics of technology and its philosophical inventories, which in turns allow others - who are not familiar with the tradition - to engage with them. Recently, Allen (2010) has offered an illuminating analysis of Daoist notion of technology, but since the current paper focuses only on Confucianism, I shall set aside Allen's analysis in this paper.

${ }^{3}$ Many have already pointed out that Chinese philosophy differs from both the Anglo-American analytic tradition(s) and/or the European continental tradition(s) in its methodologies, fundamental assumptions, and basic concepts. The differences present a real challenge to do comparative philosophy. In her paper, Liu (2009) has summarised various approaches that aim to overcome this challenge. Here, I will adopt what Liu has labelled the analytic approach to Chinese philosophy. Such an approach is characterised by its focus "on the conceptual analysis of philosophical ideas, the clear formulation of argumentation, the investigation of philosophical problems and their solutions, and the posing of hypothetical thought experiments to test one's intuition. [It usually] begins with the original text, but goes further to construct a philosophical system for the original Chinese philosopher who did not do so in his writing" (Liu 2009, 8 9). See also, Wong (2009).
} 
thought. At the same time, Dao is also one of the most elusive notions too. It is so because the notion has been the focus of debates within and between various Chinese philosophical traditions, resulting in a variety of understandings of the term. ${ }^{4}$ Yet, for its importance in Chinese thought, an account of Dao is necessary in order to have a proper understanding of it. Since this paper focuses on Confucianism, I will look specifically at the notion of Dao in Confucianism. Confucians believe that the universe is organised and governed by a specific principle, which they called Dao. While Confucians use the term 'Dao' to refer to the organising and governing principle of the universe, the term is also being used in other ways. In a summary of the meaning of the term 'Dao', Van Norden pointed out that

[Dao] has several related senses. (1) The original sense was "way," in the sense of "path" or "road." It came to mean (2) "way," in the sense of "the right way to do something," or "the order that comes from doing things in the right way," (3) a linguistic account of a way to do something, or "to give a linguistic account," (4) a metaphysical entity responsible for the way things act.

(Van Norden 2000, 24)

As the summary shows, Dao has different connotations, i.e. it is, at the same time, metaphysical, epistemological, and ethico-political. In its metaphysical connotation, i.e. (4), Dao is most often associated with Heaven (Tian). ${ }^{5}$ In Confucian thought, Heaven refers to the universe, and/or when in conjunction with Earth $(D i)$ to the nature and the material world. Confucians believe Heaven is the source of all meaning and value. Heaven is said to have its own dao, i.e. the Dao of Heaven or the Heavenly Dao (Tiandao), which is the principle that organises and governs the universe and/or the material world. Although the exact meaning of Heaven is disputed in Confucianism, there are two common understandings of it. In the spiritual, religious understanding of Heaven, it is understood as the Supreme Being, who is responsible to organise and govern the material and human world(s) (Ivanhoe 2007; Huang 2007). And, in the naturalistic understanding of Heaven, it is conceptualised as the nature akin to the Natural Law tradition in modern European philosophy (Liu 2007). Either way, Heaven is conceived as the ultimate source of normativity.

\footnotetext{
${ }^{4}$ This point is aptly captured by the title of A.C. Graham's book, i.e. Disputers of the Tao: Philosophical Argument in Ancient China (Graham 1989).

${ }^{5}$ An anonymous reviewer, by referring to Ames and Rosemont's translation of The Analects, has reminded the fact that translation of Tian as 'Heaven' is not uncontroversial; Ames and Rosemont have argued that 'Heaven' has an unnecessary and undesirable connotation to the transcendental realm in Judeo-Christian tradition, which is not apparent in the Confucian tradition; and the moral (-political) connotation in the concept of Tian, which is missing in the concept of 'Heaven'. Accordingly, they think that it will be misleading to translate Tian as 'Heaven' (Ames and Rosemont 1999, 46ff). While I am aware of the problems associated with this translation and the potential merits of retaining the term 'Tian', I still choose to translate the term because of lacking a better terminology to convey the multifarious meanings of 'Tian'. Although Ames and Rosemont's approach of not translating the term may allow the concept to be understood anew, it will require a full exposition of the various meanings associated with the term, which is beyond the scope of this paper. It is hoped that readers of this paper will be reminded that 'Tian' and 'Heaven' are not perfect synonym; and, the term 'Heaven' is better understood as a technical term for Confucianism in English.
} 
It should be pointed out that the normative role of Heaven in Confucian thought is not merely negative but also positive and proactive, and that the worldview powered by Heaven is not deterministic. For Confucians, Heaven does not only sanction and rectify the wrongdoings; it also nourishes things. For human beings, Heaven bestows them with the potential to become attuned to Heaven. Everything has its own dao, which is an instantiation of the Heavenly Dao. These daos specify how things ought to be (or ought to be done). Somewhat paradoxically, however, while the Dao of Heaven specifies the goal and ideal of human beings, and in spite of the significance of Destiny (Ming) in Confucian thought, it does not predetermine people's course of action. For instance, it is stated in The Analects 15.29 that "[h]uman beings can broaden the Way - it is not the Way that broadens human beings" (Slingerland 2003, 185). It is so because only through human beings the meaning and value embodied in Heaven can be realised. In other words, the Heavenly Dao does not dictate human and social affairs; and, human beings, as followers of Dao, remain firmly at the centre of the universe.

Following from the discussion above, the epistemological connotation of Dao should be clear. Since Dao (of Heaven) refers to the principle that organises and governs the universe and/or the material world, it is epistemologically significant insofar as it specifies the good and the right ways to do things, i.e. (2). I will not discuss the details of the epistemological connotation of Dao in this paper, as it is not directly relevant to the current purpose. Still, it is worth noting that there is no sharp distinction between theoretical knowledge and practical knowledge in early Chinese thought; or, that the importance of theoretical knowledge is often downplayed. Chad Hansen has supported this view from a philosophicallinguistic perspective. He pointed out that the view of language in early China is not truth-apt but action-guiding. Language uses are evaluated in terms of rightwrong (shi-fei) not truth-false. This non-representational view of language has disfavoured the pursuit of theoretical knowledge, which aims primarily at the Truth (Hansen 1992, 14-25, 51-52, and 85-86). Furthermore, as Hansen and other commentators have pointed out, the primary concerns of Confucians - and, in general, (ancient) Chinese thinkers - are practical in nature. ${ }^{6}$ As a result, the epistemology of Confucianism differs notably from the other philosophical traditions.

Finally, the ethico-political connotation of Dao should also be clear, too. As previously noted, Heaven is the ultimate source of normativity, which includes epistemic normativity as well as moral and political normativity. Since Confucians believe that every dao is an instantiation of the Heavenly Dao, the organising and governing principles for human and social affairs, i.e. the Dao of Humanity or the Human Dao (Rendao), is thus too an instantiation of the Heavenly Dao. The Human Dao refers to the way human beings should live. ${ }^{7}$ Here, it is important to point out the uniqueness of the Human Dao as an answer to how people should live: the Human Dao chiefly focuses on people's acquisition of virtues $(D e)$ but

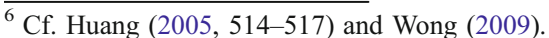

${ }^{7}$ The Human Dao also has a political dimension, i.e. it is the way the ruler should rule the people and society. Although the separation of ethics and politics in Confucianism can only be done artificially, I shall maintain this separation and ignore the political dimension in order to avoid further complications.
} 
not on establishing universalisable norms and moral principles, as Confucians believe that virtuous persons know already how to live. ${ }^{8}$ This focus on the acquisition of virtues can be explained, in part, by the relationship between human beings and Heaven in Confucian thought. While the Human Dao gains its authority from the Heavenly Dao, it is a mistake to see them as two separate principles. In Confucian thought, Heaven and Humanity are characterised by the oneness of them, i.e. the Oneness of Heaven and Humanity (Tianren Heyi), as the Confucian classics The Doctrine of Mean (Zhongyong) and Mencius (Mengzi) stated:

What Heaven (Tian, Nature) imparts to man is called human nature. To follow our nature is called the Way (Dao). Cultivating the Way is called education. The Way cannot be separated from us for a moment. What can be separated from us is not the Way...

The Doctrine of Mean, 1 (Chan 1969, 94)

To fully apply one's heart is to understand one's nature. If one understands one's nature, then one understands Heaven. To preserve one's mind and nourish one's nature is the means to serve Heaven.

Mencius 7A1 (Van Norden 2001, 149)

Accordingly, people can cultivate their nature to achieve their goal and ideal because Heaven has bestowed them with the potential to do so. People should cultivate their nature because it is to realise Dao. The emphasis, therefore, is on selfcultivation. The oneness of the Heavenly Dao and the Human Dao is too illustrated by Confucius's (Kongzi) method of learning the Dao, i.e. "[to] study what is below in order to comprehend what is above" (The Analects 14.35; Slingerland 2003, 168). Confucius's method brings forward two points concerning Dao. First, it again affirms the oneness of the Heavenly Dao and the Human Dao, i.e. the former is known through the latter. Second, it also affirms the priority of the practical in Confucianism. As Dao manifests itself in human and social affairs, Confucians believe that it is only pertinent to investigate the worldly affairs, i.e. the Human Dao, rather than the unworldly, abstract Dao of Heaven.

To sum up, Dao is the metaphysical, epistemological, and ethico-political foundation of Confucianism. While, for some, the metaphysical view and the epistemological view associated with Dao have become obsolete and doubtful because of their alleged incompatibility with a scientific worldview, the ethicopolitical dimension of Dao remains significant for the majority of contemporary Confucians. Hence, Dao is significant for the current discussion as it underlies the Confucian ethics. Based on Dao, as I will illustrate, a Confucian ethics of technology, which is unlike those that are based on typical Western ethical theories, offers an alternative way to look at moral issues pertained to technology.

\footnotetext{
${ }^{8}$ It is here that the political connotation of Dao (and/or the Human Dao) becomes significant. In Confucian thought, the paradigmatic person (Junzi) is required not only to perfect oneself, but also to help other people's self-cultivation. It is, therefore, the responsibility of the paradigmatic person to foster the good life of others, which includes, but not limits to, offering a view of the good life he or she deems appropriate.
} 


\section{Harmony in Confucianism}

The emphasis on the Oneness of Heaven and Humanity in Confucian thought has exemplified the importance of harmony in Confucianism. Confucians believe the ideal relationship between human beings and Heaven is not confrontational but harmonious, i.e. human beings are not against Heaven, neither is Heaven opposed to human beings. Depending on the view of Heaven, various interpretations of the harmonious relationship between human beings and Heaven can be elaborated. For example, it is argued that human beings and Heaven are of the same nature ontologically. Or, in the spiritual, religious understanding of Heaven, the oneness between human beings and Heaven is to achieve by following the will of Heaven. ${ }^{9}$ As an ideal relationship, harmony does not only hold between human beings and Heaven; it is an ideal relationship for within an individual and between individuals at the level of family, society, and the world. In Confucianism, special attention is given to interpersonal harmony, as Confucians believe not only that it exerts enormous influence on intrapersonal harmony, but also that it is a prerequisite for intrapersonal harmony. ${ }^{10}$

As Chengyang Li has pointed out, in Confucian thought, the harmonydisharmony distinction has the role similar to distinctions of right-wrong, goodbad, and success-failure ( $\mathrm{Li} 2006,588$ ). In this respect, harmony can be conceived as a normative standard of Confucianism. ${ }^{11}$ Its role in defining the view of the good life in Confucianism, therefore, should not be overlooked. In order to see what harmony demands, however, it is necessary first to explicate the meaning of the notion. In an analysis of the notion, Kam-por Yu has succinctly summarised four key features of harmony in Confucian thought. According to Yu,

1. Harmony is not complete agreement

2. Harmony is not unprincipled compromise

3. Harmony is balancing one thing with another one

4. Harmony is the mutual complementation of acceptance and rejection. Yu $(2010,21-25)$

To clarify the notion of harmony in Confucianism, each of the four features requires further explanation.

\footnotetext{
${ }^{9}$ For an overview of various interpretations of the oneness between Heaven and Humanity, see Keping Wang (2007).

${ }^{10}$ This is evidenced by the Confucian dictum in The Great Learning (Daixue), i.e. "to cultivate the person", "to regulate the family", "to order well the States", "to illustrate illustrious virtue throughout the empire" (Legge 1861, 221-222). And, it is stated in The Great Learning VII.1 that, "[...] 'The cultivation of the person [...]' may be thus illustrated-If a man be under the influence of passion he will be incorrect in his conduct. He will be the same, if he is under the influence of terror, or under the influence of fond regard, or under that of sorrow and distress" (Legge 1861, 232). In the original text, the literal meaning of "to cultivate the person" is to cultivate the body (Shen), and it is to be achieved through rectifying one's mind. Without going into the details of interpretation, it is clear from the passage that the interpersonal relationships, e.g. in family, states, and the empire, are depended on intrapersonal states, i.e. person (or body). See, e.g. Wang (2010) for a discussion of the importance of (harmonious) body in Confucian ethics.

${ }^{11}$ In effect, Li has gone further to argue that harmony is the normative standard of Confucianism (Li 2006, 589).
} 
The first and second features remind of the need to distinguish sameness (Tong) from harmony. Harmony and sameness are explicitly set apart in Confucianism. For instance, in The Analects 13.23, it is stated that: "The gentleman [i.e. Junzi] harmonizes ( $\mathrm{He}$ ), and does not merely agree (Tong). The petty person agrees, but he does not harmonize" (Slingerland 2003, 149). At the heart of the difference is the idea of creative dynamics, which Confucians believe to be essential to human flourishing. Aiming only at complete agreement leads to mutual reinforcement, but it does not promote creative exchanges. In other words, it only maintains the status quo, and it does not contribute to advancement or growth. Harmony differs from complete agreement because it is mutually beneficial to the involved parties, which is made possible by their creative dynamics. Hence, unlike sameness, which precludes difference and diversity, harmony presupposes them.

Similarly, harmony is not unprincipled compromise, as compromise per se is not conducive to mutual enrichment. For Confucians, unprincipled compromise is even detrimental to harmony. ${ }^{12}$ Since Confucians believe that people and things have their roles and functions, unprincipled compromise is, in effect, a form of suppression and/or repression of their proper roles and functions, which is going to result in disharmony. Hence, a relationship sustained by an unprincipled compromise cannot be considered as genuinely harmonious. In other words, a genuine harmonious relationship must be backed by reasons. ${ }^{13}$

The third and fourth features explain how harmony is to be achieved. As $\mathrm{Yu}$ has pointed out, three types of analogy are often used in the Confucian classics to explain the notion of harmony, i.e. the cooking analogy, the music analogy, and the health analogy (Yu 2010, 18-20). What is in common in those analogies is that their success depends on coordination between those elements involved, where the coordination calls for the elements (1) to perform their own roles and functions, (2) to relate to other elements in an appropriate way and (3) to not to over-power, or even dominate, other elements. Harmony, thus, requires balancing the things so that they complement and support each other. Those analogies also recapitulate the point that harmony, unlike sameness, is conducive to mutual enrichment because the outcome is always larger than the sum of its parts.

The notion of mutual complementation of acceptance and rejection may appear to be puzzling at first. It refers to the idea that harmony "is achieved only if we are able to appropriate what is acceptable in what is objectionable and denounce what is objectionable in what is acceptable" (Yu 2010, 23). This notion stems from the recognition and acceptance of the complexity in real life and from the doubt of an absolute, decontextualised goodness or rightness. For Confucians, what is good or bad, and what is right or wrong, can only be determined in a concrete situation, in which particularities become salient. Harmony is achieved by taking into account various possibilities in that situation. In other words, harmony involves contextual-

\footnotetext{
${ }^{12}$ Cf. Li (2006). As Li rightly pointed out, the notion of harmony (or harmonisation) presupposed difference. Hence, merely aiming at the elimination of difference, unprincipled compromise is, in effect, opposed to harmony.

${ }^{13}$ Cf. Yu (2010, 22)
} 
ised and holistic thinking. In practice, as $\mathrm{Li}$ (2006) has pointed out, concrete situations are seldom fixed; so, harmony can only be ensued by continuous negotiation and adjustment. In this respect, it is more appropriate to conceptualise harmony as a process, i.e. harmonisation, than a relational property or a state of affairs.

\section{On Confucian Person}

A study of Confucianism, for the purpose of illuminating its account of ethics, is incomplete without considering the Confucian notion of personhood. In the modern, Western view of personhood, which is preoccupied by a search for basic standards for the ascription of personhood, whether or not a being is a person is often determined only by the possession of certain characteristics of individuals. This view tends to define 'person' in terms of inner characteristics; and, a person is typically conceived as an independent, rational, and selfdetermining being. ${ }^{14}$ Following Michael Walzer (1994, Chapter 1), we can call this view of personhood a thin notion of personhood because it is a minimalist definition of person, which is devoid of social, cultural and historical links and meanings. In contrast to this view, we can call the Confucian notion of personhood a thick notion of personhood because, as I shall illustrate, it goes beyond the minimalist definition and is inherently social, cultural, and historical. At risk of oversimplification, from the Confucian perspective, the notion of personhood provides answers to ethico-political issues at every level. It is so because the Confucian notion of personhood is ethical by definition. As Erika Yu and Fan Ruiping have nicely characterised, the Confucian person is relational, developmental, and virtue-based (Yu and Fan 2007, 175-176). In order to see how the Confucian notion of personhood answers the ethico-political issues, different aspects of the Confucian person, i.e. relational, developmental, and virtue-based, must be elaborated in more detail. ${ }^{15}$

Few commentators would dispute the claim that the Confucian person is relational. Confucians think that human beings are inherently social and interdependent. David Wong pointed out that Confucianism presupposes a "social conception of the persons", which refers to the view that human beings are "biological organisms and become persons by entering into relationship with others of our kind." He also pointed out that Confucians posit human beings to be interdependent by nature, as human beings "need the help of others to develop as

\footnotetext{
${ }^{14}$ For a discussion of the modern, Western notion of personhood, see Bockover $(2010,307-308)$, Yu and Fan $(2007,175)$.

${ }^{15}$ Before proceeding to the discussion of the Confucian notion of personhood, one serious misconception of the Confucian self, which is often associated with the Confucian notion of personhood, has to be resisted. It is often claimed that Confucianism prioritises the community/collective over the selfl individuals. This claim amounts to a distortion of Confucianism, i.e. to say that Confucians prioritise the community/collective requires a sharp distinction between the community/collective and the self/ individuals, but, as many commentators have already pointed out, there is no sharp distinction as such in Confucianism. See, e.g. Wong (2004, 420), Lai (2006).
} 
agents"16 (Wong 2004, 420-421). In other words, Confucians think that human beings are inescapably born into a web of social relationships, and that they can only mature within the web of social relationships. This is exactly why harmonisation, which involves a continuous negotiation and adjustment of interpersonal relationship for the sake of mutual enrichment, is seen as an ideal in Confucianism. Of course, there are similar relational views of personhood in other philosophical traditions, what distinguishes the Confucian notion of personhood from them is the weight it places on familial relationships and on social role.

Confucians take familial relationships to be of utmost importance. They argue that family is the very first social context where human beings learn to relate to and interact with others appropriately. They also argue that natural familial affections found in the parent-child relation form the basis of 'love' towards others. For Confucians, therefore, family plays a principal role in shaping one's personhood. Moreover, the importance of familial relationships in Confucianism is further illustrated by their effort to model all socio-political relationships upon the familial relationships.

Also important to the Confucian notion of person is the social roles one occupies. In Confucianism, to be a person is to stand in some relations to others appropriately; and, to stand in some relations to others appropriately means that one assumes and fulfils the responsibilities the relations require. Consider, for example, the five basic types of human relations (Wulun) in Confucianism: parent-child, sibling, husbandwife, ruler-minister, and friendship; according to Confucians, each pair of human relations embodies a set of proper conduct and attitude, e.g. whether one is properly a parent is determined by his or her acceptance and fulfilment of the responsibilities to his or her child via following the set of proper conduct and attitude; and, the same holds for other human relations too. In short, to be a Confucian person is to stand in some relations to others, and those relations are to be understood prescriptively. So, a Confucian person cannot be defined independent of others; it has to be defined in terms of the social roles a person occupies. ${ }^{17}$

To call the Confucian person developmental is to see the Confucian personhood as an ongoing process. Confucians regard personhood to be neither static nor given. It is not static because persons cannot be identified with any sets of characteristics of individuals. It is not given because, in Confucian thought, while every human being is endowed with the potential to be a person, whether or not human beings become persons depends on their preservation and cultivation of the potential bestowed on them. In other words, human beings are not born persons, and they learn and practise to be persons. In this respect, the Confucian notion of personhood is aptly labelled by Roger Ames and David Hall as "person-making" (Hall and Ames 1987). Since human beings are endowed with the potential to be persons, they only need to preserve and cultivate the potential in order to become persons. Hence, "personmaking" is essentially about self-cultivation. In Confucianism, given the relational

\footnotetext{
${ }^{16}$ David Wong labelled the interdependent nature of personhood "the developmental sense of relationality" (Wong 2004, 421). His use of the term "developmental" differs significantly from the use of "developmental" in the paper by Yu and Fan (2007), where Yu and Fan use the term to characterise the Confucian notion of personhood has to be understood as a process. In this section, I am using the term in the sense suggested by $\mathrm{Yu}$ and Fan.

${ }^{17}$ Cf. Nuyen (2009).
} 
nature of personhood, self-cultivation is about learning and practice of relating to and interacting with others appropriately. While one can learn and practise to be a person, one can too degrade into non-person due to failure to assume and fulfil the required responsibilities. For example, a parent who fails to provide sufficient love, care and guidance to his or her child is merely a beast in the Confucian perspective. Since there is the possibility for a person to degrade into non-person, being a person is literally an ongoing process. In effect, the paradigmatic person (Junzi) in Confucianism is a person who is always able to respond to different relationships and in various concrete situations with propriety.

Finally, it should be obvious why the Confucian notion of personhood is virtuebased. Confucians think that personhood is defined in terms of virtue(s). For instance, in The Doctrine of Mean 20, it is stated that: "Humanity (Ren) is [the distinguishing characteristic of] man" (Chan 1969: 104). Ren, often translated as 'humanity', 'benevolence', or 'goodness', is seen as the ultimate virtue in Confucianism (Wong 2008). Here, it is important not to mistake the quote to claim that having the virtue in itself suffices for personhood. Recall the developmental nature of the Confucian person: to be a person, it is not enough to have the virtue, what is necessary is the realisation of the virtue within the web of social relationships. Since Confucians think that the realisation of ren requires one to live a specific way of life informed by the social roles one occupies, the Confucian notion of personhood has to be seen as a thick notion.

\section{Confucian Ethics: the Basics ${ }^{18}$}

To sum up the discussion so far, I have elaborated three central notions in Confucianism, i.e. Dao, harmony, and personhood. In contrast to typical Western ethical theories, those notions proffer an alternative account of ethics. In this section, using the notions I have so far elaborated, I will outline an account of Confucian ethics, which, I hope, can form the basis for further discussions. Before outlining the account of Confucian ethics, however, it is helpful to begin by looking at one major divergence between typical Western ethical theories and Confucian ethics, i.e. the relation between the right and the good.

Typical Western ethical theories assume a separation of the right and the good, as well as a prioritisation of either one over the other. ${ }^{19}$ Unlike those theories, neither

\footnotetext{
${ }^{18}$ In this section, I will only focus on Confucian normative ethics. In a paper, Liu (2007) has offered an interesting analysis of Confucian meta-ethics in terms of moral realism. While Liu's analysis is not uncontroversial, I think Liu is right to conceptualise Confucian ethics as a type of moral realism. Yet, because the details of Confucian meta-ethics will have little impact on the current discussion, I shall leave aside the questions concerning Confucian meta-ethics.

${ }^{19}$ The separation of the right and the good in typical Western ethical theories is, I think, best captured by Charles Taylor's claim that "[contemporary moral philosophy...] has tended to focus on what is right to do rather than on what is good to be, on defining the content of obligation rather than the nature of the good life" (Taylor 1989, 3). Still, as an anonymous reviewer has pointed out, to describe the Western ethical theories as a whole committed to the separation is obviously an oversimplification. I contend that the differences I have identified in this section should be taken cautiously, and that there are plenty of exceptions in 'typical Western ethical theories'. However, I still see the differences, at least, being heuristically useful and correct broadly construed.
} 
the distinction nor the prioritisation of the right and the good is important in Confucian ethics. ${ }^{20}$ I have already illustrated that Dao is the ultimate source of normativity in Confucianism; it is constitutive of both the right and the good. For instance, as the goal and ideal of human beings in Confucianism is oneness of Heaven and Humanity, which is to be attained through the realisation of Dao, the realisation of Dao has epitomised human flourishing, i.e. the good. At the same time, Dao has also delimited the right ways of its realisation, too. As Erin Cline has illustrated it with the following passage from The Analects 4.5: "Wealth and honors are things that all people desire, but unless they are acquired by following the Way $[\mathrm{Dao}]$ they are not worth having. Poverty and disgrace are things that all people hate, and yet unless they are avoided by following the Way [Dao] they are not worth avoiding" (Cline 2009, 113). What this passage conveys is that even if something is good, when pursuing it in a way that goes against Dao, a person should not do so. Here, note that the normative standard is not the right per se but Dao. Referring to this and other passages in The Analects, Cline has argued that Dao is prior to both the right and the good in Confucian ethics. Whether her claim that Dao is prior to the right and the good is true or not, I think, she has rightly emphasised that the right and the good are intermingled in Confucian ethics.

The claim that the distinction and the prioritisation are unimportant in Confucian ethics can be illustrated by the notion of harmony too. In the discussion of harmony, I have pointed out that continuous negotiation and adjustment for harmony is the right thing to do. At the same time, however, it should be clear that a harmonious relationship, be it interpersonal or intrapersonal, is essential to human flourishing as well. Harmony, in other words, is also a good too. Moreover, in continuous negotiation and adjustment for the harmonious relations, a person has to balance his or her self-interest, i.e. the good, with other's interest, i.e. the right; and, in the process of balancing, neither self-interest nor other's interest takes priority absolutely. As I shall show later, Confucian ethics, being a form of ethics resembles moral particularism, is dubious of prioritisation in absolute terms.

Let us now turn to Confucian ethics in more detail. Given the importance of selfcultivation and virtues in Confucian ethics, many commentators believe that Confucian ethics is best understood as a form of virtue ethics. ${ }^{21}$ Yet, in what sense can one characterise Confucian ethics as a form of virtue ethics? Justin Tiwald has identified two definitions of contemporary virtue ethics of which Confucian ethics may fittingly be labelled as virtue ethics. He pointed out, on one hand, that in one definition of virtue ethics, "[i]t presupposes that virtue (or perhaps approximate notions like flourishing) is more basic than rules of action and the maximization of good states of affairs, [...] the explanatory primacy of virtue [is] definitive of virtue ethics" (Tiwald 2010, 56). On the other hand, he noted that virtue ethics can be defined as the view that "in engaging in higher-order moral reflection, the first or primary task should be to understand things like the nature, psychological structure

\footnotetext{
${ }^{20} \mathrm{Cf}$. Cline (2009). I contend that, indeed, some researchers have argued that the good is prior to the right in Confucianism. But, as it should be clear later, a prioritisation of the good can only be done artificially. I believe the prioritisation of the good is proposed mainly for heuristic reason, that is - to contrast Confucianism with (Rawlsian) Liberalism, which holds that the right is prior to the good.

${ }^{21}$ For a state-of-the-art review of Confucian ethics and virtue ethics, see Tiwald (2010). See also, Lai (2006, 114-116).
} 
and ways of cultivating good character, rather than the principles of right action or their relationship to various goods. [E]thics, when done rightly, attends to character first" (Tiwald 2010, 60). Tiwald's characterisation of Confucian ethics with these two definitions is illuminating, and he has supported his claim by numerous recent works. Yet, as Lai (2006) has noted cautiously, rendition of Confucian ethics entirely as contemporary virtue ethics may risk losing insight of Confucian ethics (Lai 2006, 116). And, the problem is especially acutely in Tiwald's first definition. Confucianism, as I have elaborated, has placed special attention to social role and the need of learning and practice, which "the explanatory primacy of virtue" fails to capture in its entirety. ${ }^{22}$

In Confucian ethics, a person's social roles are morally significant because they specify his or her responsibilities in the web of relationships. Corresponding to each of the social roles, there is a set of proper conduct and attitude. It is only through following that set of proper conduct and attitude, he or she can realise Dao, i.e. that his or her choices and behaviours are considered right and good. In this respect, social roles are both normative and motivational. They determine what we ought to do and provide us the reason for doing it. Given the importance of social roles and the corresponding sets of proper conduct and attitude, the learning of them is essential to Confucians. Here, to know what one ought to do is to know what social roles he or she occupies and, relatedly, the sets of proper conduct and attitude associated with the social roles. Yet, it has to be pointed out that learning about one's social roles necessarily involves practice. The connection between learning and practice is exemplified by Confucian notion of rectifying names (Zhengming), i.e. to rectify oneself to fit the title. For example, a parent ought to act what a parent is supposed to act, and any failures and deficiencies on his or her part must be rectified to fit what the name calls for; otherwise, he or she is not a parent. Hence, learning always involves practice, because by learning about the social roles and the sets of proper conduct and attitude, one is required to act out what he or she has learnt.

There is another route to demonstrate the importance of practice for Confucians. In the discussion of the Confucian notion of personhood, I have noted that being a person is an ongoing process, which a person needs to guard him or herself from degrading into a non-person. Being a person, in effect, is practising personhood. Yet, the purpose of practising personhood is not only negative but positive too. Practising personhood, i.e. appropriately relating to and interacting with the others in various concrete situations, enables a person to cultivate his or her moral sensitivity to the others and to the morally significant factors in the situation, which then allows him or her to comprehend relationships and situations more accurately and, thus, to respond with propriety more effortlessly (Lai 2006, 117-118 and 121-122).

The emphasis on practice, arguably, is the result of Confucian ethics' focus on the paradigmatic person in its discussions of ethico-political issues. According to Antonio Cua,

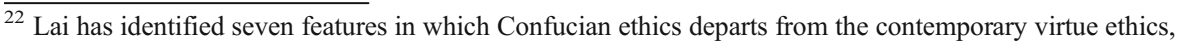
they are respectively, "[i] attention to roles and their corresponding obligations, [ii] consideration of what is right, [iii] connection between character and moral motivation, [iv] an ethic that is both act- and agentcentred, [v] the primacy of practice, [vi] a method of argumentation that prefers arbitration to adjudication and [vii] reasoned judgment based on what is the right or fitting thing to do" (Lai 2006, 116). Here, I shall focus on (i), (v), and (vii) for their immediate relevance for my account of Confucian ethics of technology.
} 
In Confucian ethics, there is no straightforward application of moral and ritual rules. There are neither 'rules of relevance' nor 'rules of inference' for concrete moral performance... [The Confucian paradigmatic person (Junzi)] is a paradigmatic guide for ordinary moral agents by virtue of his ability to cope with the changing circumstance within the Confucian moral point of view.

(Cua 1971, 52-3; Quoted in Lai 2009, 81)

There is no straightforward application of moral and ritual rules because Confucians recognise and accept the complexity in real life. Accordingly, there are rarely situations that are (nearly) identical so as to warrant straightforward application of moral and ritual rules without the need to grant exceptions. At the same time, concrete situations are deemed too complex to be accounted for by any absolute standard. More important, perhaps, is the ideal of harmony in Confucianism. As I have illustrated, harmonisation requires one to balance different factors in a concrete situation, it also requires one to take into account various pros and cons and to arrive at an 'in-between' position of the mutual complementation of acceptance and rejection. For Confucians, therefore, ethical thinking and deliberation must incorporate the particulars in the concrete situations. ${ }^{23}$ In this respect, Confucian ethics can be seen as a mild form of moral particularism, as it rejects the plausibility of moral principles and their application in concrete situations. As Lai pointed out, the rejection of moral principles and the focus on the paradigmatic person lead to the questions about know-how, e.g. "how to deliberate with reasons?", "how does one learn to be a paradigmatic person or a'competent moral judge'?" (Lai 2009, 81). In short, Confucian ethics regards ethical thinking and deliberation as a skill. And, ethical thinking and deliberation, being conceptualised as a skill, has reinforced the importance of practice in Confucian ethics.

Tiwald's second definition of Confucian ethics as virtue ethics, I contend, is less problematic. It is true to characterise Confucian ethics as an ethics that "attends to character first." More specifically, the aim of Confucian ethics can be thought of as self-modification and self-transformation, e.g. to become a paradigmatic person. In Confucianism, this self-modification and self-transformation is to be achieved via self-cultivation. As Joel Kupperman (2010b) has pointed out, in contrast to typical Western ethical theories, which exclude the private sphere from ethical thinking and deliberation, Confucian ethics does not distinguish the private sphere and the public sphere as clearly. It is so not only because there are difficulties to divide the private and the public in Confucianism, as one's personhood is essentially co-authored by him or herself and the others within his or her web of relationships; it is also because

\footnotetext{
${ }^{23}$ In The Analects, Confucius was recorded to have offered different answers to the same question, e.g.

'Zilu inquired, 'On learning something, should one act upon it?' The Master said, 'While your father and elder brothers are still alive, how could you, on learning something, act upon it?' Then Ranyou asked the same question. The Master replied, 'On learning something, act upon it.' Gongxi Hua said, 'When Zilu asked the question, you observed that his father and elder brothers are still alive, but when Ranyou asked the same question, you told him to act on what he learns. I am confused - could you explain this to me?' The Master replied, 'Ranyou is diffident, and so I urged him on. But Zilu has the energy of two, and so I sought to rein him in."”
}

(Ames and Rosemont, Jr., 1998, 146-7; Quoted in Lai 2009, 79) 
Confucians believe that one's conduct and attitude in private life will be carried onto his or her public life. This is so because Confucians believe that the kind of person one developed into over a period of time will manifest, albeit to varying extent, in both his or her private life and public life. As such, the ways one lives-his or her lifestyles - matter, particularly if one is interested in self-modification and selftransformation (Kupperman 2010b, 17-22). This is why Confucians have stressed the importance of rites $(\mathrm{Li})$, which, to put it in simplified terms, refers to the set of proper conduct and attitude associated with a social role. In following rites, a person internalises the set of proper conduct and attitude; thus, modifying him or herself to realise Dao, and, simultaneously, he or she is self-transforming in the direction of the paradigmatic person. In short, the scope of Confucian ethics is broader than typical Western ethical theories: it looks at the possibility to amelioration of oneself; and, it looks at the private sphere by studying the lifestyles that may be conducive to one's self-modification and self-transformation.

\section{Concluding Remarks: Towards a Confucian Ethics of Technology}

In the previous sections, I have introduced three major notions in Confucianism, and outlined an account of Confucian ethics. The purpose of this exercise is to summarise the potential resources for developing a Confucian ethics of technology. To end this paper, I will outline a preliminary account of ethics of technology in a Confucian perspective using the resources I have summarised. My purpose of offering the preliminary account is to demonstrate, in what ways, Confucian ethics can contribute to issues in ethics and technology. However, as the aim of this paper is largely introductory and exploratory, it is not my intention to offer a fully developed account in this paper, and I shall only highlight four major considerations that should be characteristic of a Confucian ethics of technology:

1. The priority of Dao. In Confucian ethics, there is neither a sharp distinction between the right and the good nor a prioritisation of one over the other. Realisation of Dao is conceived as the ultimate goal and ideal of human beings. In this respect, an ethics of technology in a Confucian perspective will investigate issues pertain to what are the morally right things to do as well as what are the good things-either morally or prudentially-to do; or, more generally, what is good to be. Recently, there is already a turn towards well-being and the good life in philosophy of technology and ethics of technology (e.g. Higgs et al. 2000; Brey 2007). What distinguishes a Confucian ethics of technology from this turn towards well-being and the good life is that it does not isolate the good from the right and vice versa, for both of them are under the umbrella of Dao. Here, the Confucian ethics of technology can, at least, serve as a corrective to the focus on either the right or the good. The challenge for a Confucian ethics of technology is to bring in prudential considerations, i.e. the good, or, to incorporate moral considerations, i.e. the right and the just, in thinking about the issues in ethics and technology. 
While the notion of Dao may invite suspicion because of its connotation with a mystical notion of Heaven, it needs not to be so. As Tu Weiming, a leading contemporary Confucian, has pointed out, Dao symbolises the very possibility of "learning to be human [by] a broadening and deepening process that acknowledge the interconnectedness of all the modalities of existence defining the human condition. Through an ever-expanding network of relationships encompassing the family, community, nation, world, and beyond, the Confucian seeks to realize humanity in its all-embracing fullness" (Tu 1993, 141). It implies, in other words, only a recognition and acceptance of imperfection of human beings and the possibility of selfmodification and self-transformation for being a full person through learning and practice. In short, Dao provides a direction to ethics of technology that investigates human flourishing via technology. As such, the Confucian ethics of technology properly belongs to a form of "flourishing ethics" (Bynum 2006).

2. Harmony as an ideal. There are two distinct directions Confucians may go with harmony as an ideal. The first direction concerns with applying Confucian ethics on issues in ethics and technology, and the second direction concerns with formulating issues in ethics and technology from a Confucian perspective. In regard to applying Confucian ethics, for some, relinquishing the distinction and prioritisation of the right and the good leads to a problem in ethical thinking and deliberation, that is - what one ought to do when the right and the good come into conflict. In response to this problem, harmony (or harmonisation) steps in as the normative standard. Harmony calls for mutual enrichment for the parties involved; the problem, therefore, is not merely about right or wrong, or good or bad, but about optimisation in and of concrete situations. It means that neither the right nor the good takes priority in absolute terms. Instead, a contextualised and holistic consideration of all-things considered is what it aims for. Following the previous consideration, the ideal of harmony takes over as a normative standard in ethical analyses.

More importantly, in a Confucian ethics of technology, the ideal of harmony, as a process of harmonisation, calls for a continuous negotiation and adjustment of relationships between human beings, society and technology. As such, it does not seek a final answer to issues in ethics and technology, but to identify the possibility of harmony and disharmony in the relationships, and to preserve or to amend it. Since it does not aim at the final answers, it will formulate the issues in ethics and technology differently. As Kupperman (2010a) noted, typical Western ethical theories tend to focus narrowly on norms and moral principles for determining what is right and just. In contrast to this, a Confucian ethics of technology will be formulated in terms of know-how, focusing on learning and practising harmonisation in the technological world. This proposal may appear vague and ambiguous; but, I think, it is justifiably so. Since Confucians see ethics as a continuous process of self-modification and self-transformation, unlike most of the current research on ethics and technology, they will not formulate their enquiry in the form of a specific issue in ethics and technology. ${ }^{24}$

${ }^{24}$ This is not to say that the Confucian ethics of technology cannot be applied to issues in ethics and technology. 
How, then, should Confucians proceed in ethics and technology? Perhaps, they can learn from Borgmann's notion of focal things and practices (Borgmann 1984, 196-226). Borgmann has argued for the importance of focal things and practices, such as running and family dinners, for (re-)engaging ourselves with the meaningful lifeworld; in part, his analysis aims at identifying the qualities of things and practices that qualify them as focal. Here, Borgmann's focus on focal things and practices resonates with Confucian's emphasis on know-how and harmonisation-as-a-skill. In a spirit similar to Borgmann, then Confucians can examine various things and practices, ${ }^{25}$ and study if they promote our ability of harmonisation.

3. The significance of social role. In Confucian ethics, special attention is given to social role; and social roles are conceived as both normative and motivational. A Confucian ethics of technology, therefore, should also pay special attention to the social roles individuals occupy in the society. To be sure, the significance of professional role has already been studied in engineering ethics and other professional ethics, but the notion of social role in a Confucian ethics of technology has to be conceived much broader. It should include familial, communal roles, etc. Confucians believe that social roles are constitutive of personhood; so, particular weight will be given to the social roles in ethical thinking and deliberation. This implies that an ethics of technology needs to scrutinise more carefully the nature of specific social roles and the responsibilities associated with them. In other words, it promotes a turn towards a rolebased ethics in ethics of technology. ${ }^{26}$

In a recent paper, Philip Brey has urged philosophers of technology to look more closely at technology-society relations, and to examine how technology interacts with various social structures, institutions and processes, cultural practices and beliefs, etc. (Brey 2010, 46). In a similar vein, a Confucian ethics of technology should urge researchers to examine how technology has influenced and/or transformed the nature of specific social roles and the responsibilities associated with them. However, such an endeavour is not merely historical or sociological, i.e. to discover what have changed in light of technology; it is normative, too. ${ }^{27}$ Recall the Confucianism's emphasis on social role: it maintains every social role is specified by a set of responsibilities. Its ethics of technology, therefore, should begin from social roles and the role responsibility. Since technologies can either enhance or deter people's fulfilment of their role responsibility, and they can also change nature of the social roles, Confucians may evaluate them in terms of their impacts on social roles. For instance, from a Confucian perspective, the issues related to online friendship is not to be formulated in terms of the preconditions for friendship in the online

\footnotetext{
${ }^{25}$ In accordance with Confucian ethics, the primary emphasis should be on practices; but, since we are talking about technologically mediated practices, things, i.e. technologies, cannot be isolated.

${ }^{26}$ In a Confucian ethics of technology, there is also the possibility to look at the social roles technologies occupies. Notice that in proposing the analysis of the social roles play by technologies, it does not imply an instrumentalist view of technology, i.e. just as being a friend is a role and has a set of responsibilities, it does not entail being a friend is merely instrumental, and the same can be true of technology, too.

${ }^{27}$ I would like to thank an anonymous reviewer who brought this issue to my attention.
} 
world (e.g. Cocking and Matthews 2001; Briggle 2008). Rather, it is to be examined via the responsibilities associated with being a friend. ${ }^{28} \mathrm{It}$, in turns, demands researchers to start from the role responsibility of being a friend. There are a number of interesting studies of the Confucian notion of friendship available, but they have yet to be applied to issues related to online friendship. ${ }^{29}$

4. The significance of practice and lifestyle. Finally, the emphasis on social role and the role responsibility is closely connected to the emphasis of practice in Confucian ethics. In order to perform a social role properly, Confucians have stressed that a person must learn and practise it. Translating it into a Confucian ethics of technology, it promotes an investigation of the kinds of actual and/or potential practices engendered by technology and a study of whether those practices are conducive or detrimental to our performance of the social roles. Looking at practices, it also marks the possibility of modification and transformation of oneself through the uses of technologies. Self-modification and self-transformation, however, is not only restricted to the public sphere; indeed, it happens more often in the private sphere. Hence, it is important to look into the ways one lives in light of technologies, i.e. the lifestyle. This is very similar to what Peter-Paul Verbeek calls "accompanying technology", i.e. "to accompany the development, use, and social embedding of technology" (Verbeek 2010, 52). For Verbeek, accompanying technology primarily amounts to an ethics of design for the designers of technology (Verbeek 2006, 2008, 2009). For Confucians, accompanying technology will primarily involve users thinking and incorporating technologies creatively into their daily life. ${ }^{30}$ In short, it promotes a turn towards the ameliorative aspects of technology.

Admittedly, the account of Confucian ethics of technology is far from complete, and the examples are far from conclusive. But, I have made no pretence that they are either complete or conclusive. To reiterate the purpose of the current paper, it aims to initiate an uncharted field of philosophy of technology and ethics of technology by exploring another philosophical tradition, i.e. Confucianism, identifying the connections it has with other theories, and suggesting possible ways in which it can contribute to the issues related to ethics and technology. Further research is needed to fully develop a comprehensive account of Confucian ethics of technology, but I hope this paper will provide the groundwork for future research.

\footnotetext{
${ }^{28}$ Cf. Vallor (2011). In Vallor (2011), she has analysed online friendship from the perspective of virtue ethics. There are many similarities in her analysis to the Confucian perspective mentioned here. But, as I have pointed out, virtue ethics has primarily focused on individual's qualities (or characters), whereas in Confucian ethics, the emphasis is on the social role and the role responsibility. In short, the example offered here differs from Vallor's in that it starts with a normative and motivational account of friendship, but not the personal qualities (or characters).

${ }^{29}$ See, e.g. Lai (1996), Hall and Ames (1998, 257-269), and Mullis (2010).

${ }^{30}$ While it is not exactly from a user-perspective, I think the TED talk given by Cynthia Breazeal on The Rise of Personal Robots (http://www.ted.com/talks/cynthia_breazeal_the_rise_of_personal_robots.html) has nicely illustrated the potential of the Confucian ethics of technology I have elaborated in the current paper. In the talk, she has presented an application of robot for tele-presence, and interestingly, she has discussed its potential to extend people's capacity to fulfil their role responsibility (in her story, grandparent's).
} 
Acknowledgements Early version of this paper was presented at The Netherlands School for Research in Practical Philosophy's Ethics and Technology Working Group Meeting in December 2010. I want to thank Wang Xiaowei (Tom) and other participants of the meeting for their comments and suggestions. I would also like to thank Dr. Yu Kam-por, Acting Director/Senior Lecturer of General Education Centre at Hong Kong Polytechnic University for his valuable advice. Finally, the paper has benefited enormously from the helpful remarks of three anonymous reviewers.

Open Access This article is distributed under the terms of the Creative Commons Attribution Noncommercial License which permits any noncommercial use, distribution, and reproduction in any medium, provided the original author(s) and source are credited.

\section{References}

Allen, B. (2010). A Dao of technology? Dao, 9(2), 151-160.

Ames, R., \& Rosemont, H. (1999). The analects of Confucius: a philosophical translation. New York: Ballantine Books (trans.).

Bockover, M. I. (2003). Confucian values and the internet: a potential conflict. Journal of Chinese Philosophy, 30(2), 159-175.

Bockover, M. I. (2010). Confucianism and ethics in the western philosophical tradition i: foundational concepts. Philosophy Compass, 5(4), 307-316.

Borgmann, A. (1984). Technology and the character of contemporary life: a philosophical inquiry. Chicago: University of Chicago Press.

Brey, P. (2007). Theorizing the cultural quality of new media. Techné: Research in Philosophy and Technology, 11(1), 1-18.

Brey, P. (2010). Philosophy of technology after the empirical turn. Techné, 14(1), 36-48.

Briggle, A. (2008). Real friends: how the internet can foster friendship. Ethics and Information Technology, 10(1), 71-79.

Bynum, T. W. (2006). Flourishing ethics. Ethics and Information Technology, 8(4), 157-173.

Capurro, R. (2008). Intercultural information ethics. In K. E. Himma \& H. T. Tavani (Eds.), Handbook of information and computer ethics (pp. 639-665). Hoboken, NJ: Wiley.

Capurro, R. (2010). The Dao of the Information Society in China and the task of intercultural information ethics. Available from: http://www.capurro.de/china_infoethics2010.html. Accessed 20 Jan 2011.

Chan, W.-T. (1969). A source book in Chinese Philosophy. Princeton, NJ: Princeton University Press (trans.).

Cline, E. M. (2009). The way, the right, and the good. Journal of Religious Ethics, 37(1), 107-129.

Cocking, D., \& Matthews, S. (2001). Unreal friends. Ethics and Information Technology, 2(4), 223-231.

Ess, C. (2006). Ethical pluralism and global information ethics. Ethics and Information Technology, 8(4), 215-226.

Ess, C. (2007a). Cybernetic pluralism in an emerging global information and computer ethics. International Review of Information Ethics, 7, 94-123.

Ess, C. (2007b). Universal information ethics? Ethical pluralism and social justice. In E. Rooksby \& J. Weckert (Eds.), Information technology and social justice (pp. 69-92). Hershey, PA: Idea Group Reference.

Ess, C. (2008). Culture and global networks: hope for a global ethics? In J. van den Hoven \& J. Weckert (Eds.), Information technology and moral philosophy (pp. 195-225). Cambridge; NY: Cambridge University Press.

Ess, C. (2009). Digital media ethics. Cambridge: Polity.

Ess, C., \& Hongladarom, S. (2007). Information technology ethics: cultural perspectives. Hershey, PA: Idea Group Reference.

Ess, C., \& Thorseth, M. (2010). Global information and computer ethics. In L. Floridi (Ed.), The cambridge handbook of information and computer ethics (pp. 163-180). Cambridge; NY: Cambridge University Press.

Fan, R. (Ed.). (1999). Confucian bioethics. Dordrecht: Kluwer Academic Publishers.

Franssen, M., Lokhorst, G-J and van de Poel, I. (2010). Philosophy of technology. In E. N. Zalta (Ed.), The Stanford Encyclopedia of Philosophy (Spring 2010 Edition). Available from: http://plato.stanford. edu/archives/spr2010/entries/technology/. Accessed 20 Jan 2011.

Graham, A. C. (1989). Disputers of the tao: philosophical argument in ancient China. La Salle, Ill.: Open Court. Hall, D. L., \& Ames, R. T. (1987). Thinking through confucius. Albany, N.Y.: State University of New York Press.

Hall, D. L., \& Ames, R. T. (1998). Thinking from the han: self, truth and transcendence in Chinese and Western culture. Albany, N.Y.: State University of New York Press. 
Hansen, C. (1992). A Daoist theory of Chinese thought: a philosophical interpretation. New York: Oxford University Press.

Higgs, E., Light, A., \& Strong, D. (2000). Technology and the good life? Chicago: University of Chicago Press.

Huang, Y. (2005). Some fundamental issues in Confucian ethics: a selective review of encyclopedia of Chinese philosophy. Journal of Chinese Philosophy, 32(3), 509-528.

Huang, Y. (2007). Confucian theology: three models. Religion Compass, 1(4), 455-478.

Ivanhoe, P. J. (2007). Heaven as a source for ethical warrant in early Confucianism. Dao, 6(3), 211-220.

Kupperman, J. J. (2010a). Why ethical philosophy needs to be comparative. Philosophy, 85, 185-200.

Kupperman, J. J. (2010b). Confucian civility. Dao, 9, 11-23.

Lai, K. (2003). Conceptual foundations for environmental ethics: a daoist perspective. Environmental Ethics, 25, 247-266.

Lai, K. (2006). Learning from Chinese philosophies: ethics of interdependent and contextualised self. UK: Ashgate.

Lai, K. (2009). Judgment in Confucian ethics. Sophia, 48, 77-84.

Lai, W. (1996). Friendship in Confucian China. In O. Leaman (Ed.), Friendship East and West: philosophical perspectives (pp. 215-250). Surrey: Curzon.

Legge, J. (trans.) (1861). The Chinese Classics, with a translation, critical and exegetical notes, prolegomena, and copious indexes, Volume 1. Hong Kong

Li, C. (2006). The Confucian ideal of harmony. Philosophy East and West, 56(4), 583-603.

Liu, J. L. (2007). Confucian moral realism. Asian Philosophy, 17(2), 167-184.

Liu, J. L. (2009). Converting Chinese philosophy into the analytic context. Available from: http:/faculty. fullerton.edu/jeelooliu/Liu_Analytic-Chinese.pdf. Accessed 20 Jan 2011.

Meijers, A. (Ed.). (2009). Philosophy of technology and engineering sciences. Amsterdam: Elsevier.

Mullis, E. (2010). Confucius and aristotle on the goods of friendship. Dao, 9(4), 391-405.

Nuyen, A. T. (2009). Moral obligation and moral motivation in Confucian role-based ethics. Dao, 8 , $1-11$.

Olsen, J. K. B., Selinger, E., \& Riis, S. (Eds.). (2009a). New waves in philosophy of technology. Basingstoke, New York: Palgrave Macmillan.

Olsen, J. K. B., Pedersen, S. A., \& Hendricks, V. F. (Eds.). (2009b). A companion to the philosophy of technology. UK: Wiley-Blackwell.

Slingerland, E. (2003). Confucius Analects: with selections from traditional commentaries. Indianapolis, IN: Hackett Pub Co. (trans.).

Taylor, C. (1989). Sources of the self: the making of the modern identity. Cambridge, MA: Harvard University Press.

Tiwald, J. (2010). Confucianism and virtue ethics: still a fledgling in Chinese and comparative philosophy. Comparative Philosophy, 1(2), 55-63.

Tu, W. (1993). Confucianism. In A. Sharma (Ed.), Our religions (pp. 139-227). New York: Harper Collins.

Vallor, S. (2011) Flourishing on Facebook: virtue friendship and new social media. Ethics and Information Technology.

Van Norden, B. (2000). Confucius and the analects: new essays. Oxford: Oxford University Press.

Van Norden, B. (2001). Mengzi (Mencius). In P. Ivanhoe \& B. Van Norden (Eds.), Readings in Classical Chinese Philosophy (pp. 115-159). New York, NY: Seven Bridges Press (trans.).

Verbeek, P. P. (2006). Materializing morality-design ethics and technological mediation, science. Technology and Human Values, 31(3), 361-380.

Verbeek, P. P. (2008). Morality in design: design ethics and the morality of technological artifacts. In P. Kroes, P. Vermaas, A. Light, \& S. Moore (Eds.), Philosophy and design: from engineering to architecture (pp. 91-103). Dordrecht: Springer.

Verbeek, P. P. (2009). The moral relevance of technological artifacts. In P. Sollie \& M. Duwell (Eds.), Evaluating new technologies: methodological problems for the ethical assessment of technology developments (pp. 63-77). Dordrecht: Springer.

Verbeek, P.-P. (2010). Accompanying technology: philosophy of technology after the ethical turn. Techné, 14(1), 49-54.

Walzer, M. (1994). Thick and thin: moral argument at home and abroad. Indiana: University of Notre Dame Press.

Wang, K. (2007). A rediscovery of heaven-and-human oneness. American Journal of Economics and Sociology, 66(1), 237-259.

Wang, R. (2002). Globalizing the heart of the dragon: the impact of technology on Confucian ethical values. Journal of Chinese Philosophy, 29(4), 553-569.

Wang, R. (2010). The virtuous body at work: the ethical life as $Q i$ in motion. Dao, 9, 339-351.

Wong, D. (2004). Relational and autonomous selves. Journal of Chinese Philosophy, 31(4), 419-432. 
Wong, D (2008). Chinese ethics. In E. N. Zalta (Ed.). The Stanford encyclopedia of philosophy (Fall 2008 Edition). Available from: http://plato.stanford.edu/archives/fall2008/entries/ethics-chinese/. Accessed 20 Jan 2011.

Wong, D (2009). Comparative philosophy: Chinese and Western. In E. N. Zalta (ed.). The Stanford Encyclopedia of Philosophy (Winter 2009 Edition). Available from: http://plato.stanford.edu/archives/ win2009/entries/comparphil-chiwes/. Accessed 20 Jan 2011.

Yu, E., \& Fan, R. (2007). A Confucian view of personhood and bioethics. Bioethical Inquiry, 4, 171-179.

Yu, K. P. (2010). The Confucian conception of harmony. In J. Tao, A. Cheung, M. Painter, \& C. Li (Eds.), Governance for harmony in Asia and beyond (pp. 15-36). London: Routledge. 